\title{
Characteristics of ripened Tronchón cheese from raw goat milk containing legally admissible amounts of antibiotics
}

\author{
P. Quintanilla, ${ }^{1}$ M. C. Beltrán, ${ }^{1}$ A. Molina,${ }^{2}$ I. Escriche,${ }^{3}$ and M. P. Molina ${ }^{1 *}$ \\ ${ }^{1}$ Institute for Animal Science and Technology, Universitat Politècnica de València, Camino de Vera, s/n, 46022, Valencia, Spain \\ ${ }^{2}$ Department of Science and Agroforestry Technology (ETSIA-IDR), Universidad de Castilla-La Mancha, 02071, Albacete, Spain \\ ${ }^{3}$ Institute of Food Engineering for Development, Food Technology Department, Universitat Politècnica de València, Camino de Vera, s/n, 46022, \\ Valencia, Spain
}

\section{ABSTRACT}

The aim of this study was to evaluate the transfer of the most widely used antibiotics in dairy goats from milk to cheese as well as their effect on the cheesemaking process and cheese characteristics during ripening. Antibiotic-free milk was spiked individually with 7 veterinary drugs (amoxicillin, benzylpenicillin, cloxacillin, erythromycin, ciprofloxacin, enrofloxacin, and oxytetracycline) at an equivalent concentration of the European Union maximum residue limit. Spiked goat milk was used to make mature Tronchón cheeses, which were analyzed at 0,30 , and $60 \mathrm{~d}$ of maturation to determine $\mathrm{pH}$, chemical composition, proteolytic and lipolytic activities, and color and textural properties. A sensory evaluation of $60-\mathrm{d}$ ripened cheeses was carried out. Cheeses from raw antibiotic-free goat milk were made simultaneously to be used as reference. The cheese-making process was unaffected by the presence of most antibiotics evaluated. Only erythromycin and oxytetracycline significantly increased the time required for cheese production $(122 \pm 29$ and $108 \pm 25 \mathrm{~min}$, respectively). However, variable amounts of antibiotics, ranging from 7.4 to $68 \%$, were transferred from milk to cheese, with oxytetracycline and quinolones showing the highest retention rates. In general, antibiotic residues present in the cheeses at the beginning of maturation decrease significantly along time. Thus, $\beta$-lactams and erythromycin residues were not detectable after 30 $\mathrm{d}$ of ripening. However, relatively high concentrations of enrofloxacin $(148 \pm 12 \mu \mathrm{g} / \mathrm{kg})$ and ciprofloxacin $(253$ $\pm 24 \mu \mathrm{g} / \mathrm{kg}$ ) residues were found in the cheeses after $60 \mathrm{~d}$ of maturation. The quality characteristics of the Tronchón cheeses were only slightly affected by such substances, with few significant differences in the free fatty acid concentration and color and textural properties of the cheeses. Results herein indicate that the use

Received August 10, 2018.

Accepted December 20, 2018.

*Corresponding author: pmolina@dca.upv.es of goat milk containing antibiotics, such as quinolones, at the European Union maximum residue limit for cheese production could adversely affect the safety of the final products because relatively high concentrations of these substances could be retained in soft and semi-mature cheeses, making it necessary to assess the risk for consumer health. Studies on the partition of the antibiotic substances during cheese-making, using specific technologies, would be convenient to guarantee the safety of cheese and related products.

Key words: goat milk, antibiotic, cheese ripening, drug partition

\section{INTRODUCTION}

The administration of veterinary drugs, especially antibiotics, in the treatment and prophylaxis of mastitis and other infectious diseases in dairy livestock is currently a widespread practice. However, the beneficial effects of antimicrobial therapy in lactating animals may be counteracted by the possible appearance of residues of these substances in milk. The consumption of milk or related products containing antibiotic residues can have harmful effects on human health, causing transient disturbances in the intestinal flora and allergic reactions (Stolker and Brinkman, 2005; Dethlefsen et al., 2008; Jeong et al., 2009). There is also the concern that the presence of antibiotics in foodstuffs may be responsible for the development of bioresistance (Oliver et al., 2011; FAO/OIE/WHO, 2018).

To avoid potential risks related to drug residues in food, the control of the presence of antibiotics in milk and other products of animal origin is legally binding in many countries. The US Food and Drug Administration Center for Veterinary Medicine established safe levels and tolerances of antibiotic residues in milk to protect consumers (FDA, 2018). In the European Union (EU), the regulatory levels or maximum residue limits (MRL) are defined by Regulation (EC) 470/2009 (European Union, 2009) and established by Commission Regulation (EU) 37/2010 (European Union, 2010). 
Safety levels for milk minimize the potential risk of consuming dairy products because negative effects are not expected in most cases if antibiotic residues do not exceed these thresholds. Thus, for example, pasteurized milk or yogurts made from contaminated milk generally show equal or lower concentration of antibiotics than raw milk used for their production (Grunwald and Petz, 2003; Adetunji, 2011); this is possibly related to the application of heat treatments, which tend to slightly reduce the concentration of most antibiotics (Roca et al., 2011; Gajda et al., 2018). However, in dairy products such as cheese, the residual amounts of antibiotics in the final products could be significantly affected by the elimination of most of the aqueous fraction of the milk during the elaboration process, leading to the concentration of the main components such as fat and protein.

Antibiotics could be retained in milk curd to a greater or lesser extent depending on the physicochemical properties of these substances and their ability to interact with the fat and protein fraction of the matrix (Giraldo et al., 2017; Shappell et al., 2017). The World Health Organization suggested establishing MRL of liposoluble antibiotics in milk products such as milkfat and cheese, being apprehensive that such substances might reach levels far above the initial contents in milk, thus possibly posing a risk for consumers $(\mathrm{FAO} / \mathrm{WHO}$, 2004). However, EU legislation has established only an MRL for raw milk, and safety limits for related products have not been fixed.

It should be noted that related studies currently available are scarce and focus on the transfer of tetracyclines from contaminated milk to different dairy products (Cabizza et al., 2017; Gajda et al., 2018). Information about the possible retention of antibiotics belonging to other families (e.g., $\beta$-lactams, macrolides, or quinolones) that are widely used in dairy livestock is practically unavailable. Therefore, the effect of the presence of antibiotics in raw milk on the safety of dairy products such as cheeses is currently unknown.

Besides the direct negative effects on consumer health, antibiotic residues in milk may lead to problems in the dairy industry by inhibiting the activity of starter cultures used in the production of fermented products such as mature cheese. Katla et al. (2001) evaluated antimicrobial resistance of commercial starter cultures, observing that antibiotics at concentrations below their respective MRL reduce the activity of the microorganisms such as lactobacilli or streptococci. These starter cultures produce part of the enzymes responsible for the principal biochemical pathways involved during cheese ripening (McSweeney and Sousa, 2000) and, therefore, the presence of antibiotics could affect the typical cheese texture or flavor characteristics.
In recent decades, goat milk production has increased considerably, reaching 15.3 million tonnes (FAOSTAT, 2018), as consumers have shown an increased interest in goat milk products due to their nutritional and digestive properties (Haenlein, 2004; Park, 2017). Goat milk is used to make fluid pasteurized milk and a wide range of dairy products, especially different types of cheese, often from raw milk and under Protected Designation of Origin and other recognized quality brands. However, the presence of veterinary drug residues, especially antibiotics, can jeopardize the nutritional benefits and quality of milk and cheeses. Beltrán et al. (2015) indicated that the antibiotics most commonly used in dairy goats are tetracyclines (oxytetracycline and tetracycline), $\beta$-lactams (penicillin, amoxicillin, and cloxacillin), quinolones (enrofloxacine), and macrolides (tylosin and erythromycin), and therefore control strategies in goat milk should focus on these substances.

Studies on the retention of the antibiotic during dairy manufacturing processes are crucial to prevent the negative implications related to the presence of such substances in milk products. Therefore, the aim of the present work was to evaluate the transfer of the most widely used antibiotics in dairy goats from milk to cheese as well as their effect on the cheese-making process and the cheese characteristics during ripening.

\section{MATERIALS AND METHODS}

\section{Milk Samples and Antibiotics}

Antibiotic-free milk was obtained from the experimental herd of Murciano-Granadina goats of Universitat Politècnica de València (Valencia, Spain). Animals did not receive any antimicrobial substances either before or during the experimental period. The milk chemical composition was analyzed by MilkoScan 6000 (Foss, Hillerød, Denmark), SCC by Fossomatic 5000 (Foss), and total bacterial count by Bactoscan FC (Foss). The milk $\mathrm{pH}$ value was measured by a conventional $\mathrm{pH}$ meter (model Basic 20, Crison Instruments, Barcelona, Spain). The screening test Eclipse 100 (Zeulab, Zaragoza, Spain) was used to detect inhibitors in milk.

The goat milk composition (g/100 g) had a (mean \pm SD) TS content of $14.4 \pm 0.7$, fat content of $5.3 \pm 0.5$, and protein content of $3.7 \pm 0.8$. The SCC and total bacterial count were $6.08 \log$ cells/mL and $4.76 \log \mathrm{cfu} /$ $\mathrm{mL}$, respectively, and the mean $\mathrm{pH}$ was $6.80 \pm 0.05$.

The antibiotics (commercial reference) used in this study were amoxicillin (A8523), benzylpenicillin (PENNA), cloxacillin (C9393), erythromycin (E6376), ciprofloxacin (17850), enrofloxacin (17849), and oxytetracycline (O4636), all supplied by Sigma-Aldrich Química S.A. (Madrid, Spain). A stock solution (100 
$\mathrm{mg} / 100 \mathrm{~mL}$ ) was prepared for each antibiotic trial using distilled water. For some antibiotics, the addition of $3 \mathrm{~mL}$ of a suitable solvent was necessary to dissolve the drug before adding water. These solvents, purchased from Fluka (Barcelona, Spain), were ethanol for erythromycin, acetic acid (5\%) for enrofloxacin and ciprofloxacin, and hydrochloric acid $(0.1 N)$ for oxytetracycline. Spiked milk samples were prepared to reach an antibiotic concentration equivalent to the EU MRL (amoxicillin and benzylpenicillin: $4 \mu \mathrm{g} / \mathrm{kg}$; cloxacillin: $30 \mu \mathrm{g} / \mathrm{kg}$; erythromycin: $40 \mu \mathrm{g} / \mathrm{kg}$; ciprofloxacin, enrofloxacin, and oxytetracycline: $100 \mu \mathrm{g} / \mathrm{kg}$ ) according to the recommendations of the International Dairy Federation (ISO/IDF, 2003).

\section{Cheese-Making Process}

Cheese-making trials were carried out in duplicate for each antibiotic studied at the Universitat Politècnica de València pilot plant following the artisanal process for mature Tronchón cheese, a traditional pressed cheese produced in the Maestrazgo area (Eastern Spain) from raw or pasteurized sheep, goat, or mixed milk, enzymatic coagulation, and different ripening times. For each replicate, $100 \mathrm{~kg}$ of raw goat milk was divided into two $50-\mathrm{kg}$ vats. One vat was used to make antibioticfree $(\mathbf{A F})$ cheese used as the control, whereas the other vat was used to produce cheese from spiked milk (SM) with antibiotics before cheese manufacture at EU MRL concentration.

Raw milk was inoculated with the commercial starter culture containing Lactococus lactis ssp. lactis, Lc. lactis ssp. cremoris, L. lactis ssp. lactis biovar diacetylactis, and Streptococcus thermophilus (CHOOZIT MA4001, Danisco, Sassenage, France) at 5 Danisco culture units $/ 100 \mathrm{~L}$. Milk was heated at $32^{\circ} \mathrm{C}$, and calcium chloride (Proquiga, A Coruña, Spain) at $0.013 \%$ (vol/ vol) was added. Liquid calf rennet (chymosin:pepsin 70:30, 150 IMCU; Laboratorios Arroyo, Santander, Spain) at $0.07 \%$ ( vol/vol) was used for coagulation. After coagulation $(\sim 30-40 \mathrm{~min})$, the curd was cut into grains (1-cm cubes). Subsequently, it was heated $\left(35^{\circ} \mathrm{C}\right)$ and stirred for approximately 90 min until reaching a $\mathrm{pH}$ value of $6.35 \pm 0.05$. Then, whey was drained off and the curd was distributed in cylindrical molds $(800$ g) and pressed in a pneumatic press (1.5 bars/90 min, $2.0 \mathrm{bars} / 90 \mathrm{~min}$, and $2.5 \mathrm{bars} / 20 \mathrm{~min}$ ). Ten cheeses were obtained from each elaboration. The acidification of the cheese was measured in each manufacture step, and after pressing the $\mathrm{pH}$ was checked every $15 \mathrm{~min}$ until reaching the final $\mathrm{pH}$ of $5.30 \pm 0.05$. Afterward, the cheeses were salted in brine $(23 \% \mathrm{wt} / \mathrm{vol})$ for $3 \mathrm{~h}$. Then, the cheeses were kept in an airing chamber $\left(6^{\circ} \mathrm{C}\right.$, $75 \%$ relative humidity) for $48 \mathrm{~h}$ and then in a ripening chamber under controlled conditions $\left(11-12^{\circ} \mathrm{C}, 80-85 \%\right.$ relative humidity) for 2 mo. The $60-\mathrm{d}$ period is the most commonly applied maturation time in Tronchón cheese manufacture from raw goat milk. Cheese samples for analysis were taken before $(0 \mathrm{~d})$ and during (30 and 60 d) maturation.

\section{Analysis of Antibiotic Residues in Cheese}

The extraction and purification of antibiotics in the cheeses was carried out according to the protocols established and validated at the Instituto Lactológico de Lekunberri (Lekunberri, Pamplona, Spain) according Commission Decision 2002/657/EC (European Union, 2002).

For the extraction procedure, $10 \mathrm{~g}$ of cheese samples was placed in a stomacher bag with $20 \mathrm{~g}$ of trisodium citrate (20\% wt/wt; Sigma-Aldrich) and homogenized twice for $3 \mathrm{~min}$ at $40^{\circ} \mathrm{C}$. The mixture was centrifuged at $9,000 \times g$ for $10 \mathrm{~min}$ at room temperature. Then, $2 \mathrm{~g}$ of the supernatant was extracted by solid-phase extraction (SPE) using an Oasis HLB cartridge $(60 \mathrm{mg}, 3 \mathrm{~mL}$, Waters Chromatography Division, Milford, MA) previously conditioned with $1 \mathrm{~mL}$ of methanol [liquid chromatography (LC) gradient grade, Scharlau, Barcelona, Spain] and $1 \mathrm{~mL}$ of ultrapure water (generated in-house from a Milli-Q system, Millipore Corp., Billerica, MA). After the sample had passed through the cartridge, it was rinsed with $2 \mathrm{~mL}$ of water, eluted with $2 \mathrm{~mL}$ of methanol, and dried under vacuum. After evaporation, $500 \mu \mathrm{L}$ of $0.1 \%$ formic acid (LC gradient grade, SigmaAldrich) was added and homogenized in an ultrasonic bath for $5 \mathrm{~min}$. Finally, the redissolved extracts were filtered into a chromatographic vial using a $0.45-\mu \mathrm{m}$ polyvinylidene fluoride filter (Sigma-Aldrich), and 20 $\mu \mathrm{L}$ of this mixture was injected into the LC system.

Antibiotics were analyzed using a chromatography system consisting of an LC/MS-MS Alliance 2695 with a diode-array detector (Waters Chromatography Division) and a Micromass Quattro MicroTM triple quadrupole tandem mass spectrometer (Waters Chromatography Division). An XBridge C18 column $(100 \times 34.6$ $\times 2.1 \mathrm{~mm}$, particle size of $3.5 \mu \mathrm{m}$ ) was used (Waters Chromatography Division). Chromatographic separation was carried out with a mobile phase A consisting of $0.1 \%$ ( $\mathrm{vol} / \mathrm{vol}$ ) formic acid in water and mobile phase $\mathrm{B}$ consisting of $0.1 \%$ formic acid in acetonitrile (LC gradient grade, Scharlau). The solvent gradient conditions of the mobile phase for the antibiotics (except oxytetracycline) were as follows: time $(t, \min ) \mathrm{t}_{0}, 95 \%$ $\mathrm{A}$ and $5 \% \mathrm{~B} ; \mathrm{t}_{8}, \mathrm{~A}=25 \% ; \mathrm{t}_{14}, \mathrm{~A}=5 \% ; \mathrm{t}_{15}, \mathrm{~A}=95 \%$; $\mathrm{t}_{20}, \mathrm{~A}=95 \%$. In the case of oxytetracycline analyses, the mobile phase gradient profile was $\mathrm{t}_{0}, 85 \% \mathrm{~A}$ and $15 \% \mathrm{~B} ; \mathrm{t}_{6}, \mathrm{~A}=82 \% ; \mathrm{t}_{8}, \mathrm{~A}=50 \% ; \mathrm{t}_{10}, \mathrm{~A}=50 \% ; \mathrm{t}_{15}, \mathrm{~A}$ 
$=85 \% ; \mathrm{t}_{20}, \mathrm{~A}=85 \%$. The flow rate was $0.2 \mathrm{~mL} / \mathrm{min}$. The operating parameters for the mass spectrometer were needle voltage $3.0 \mathrm{kV}$, lens voltage $0.2 \mathrm{~V}$, source block temperature $140^{\circ} \mathrm{C}$, and desolvation temperature $450^{\circ} \mathrm{C}$. Desolvation and cone gas (nitrogen) were 750 and $50 \mathrm{~L} / \mathrm{h}$, respectively. Analytes were detected using electrospray ionization in the positive ion mode. MassLynx 4.0 software (Waters Chromatography Division) was used to calculate the antibiotic concentrations in goat cheeses. The typical recoveries were approximately 85 to $100 \%$ for the $\beta$-lactams and tetracyclines, 80 to $95 \%$ for the macrolides, and 90 to $110 \%$ for the quinolones.

The calibration curves had previously been established for each antibiotic considered. The limit of quantification was equal to $2 \mu \mathrm{g} / \mathrm{kg}$ for amoxicillin and benzylpenicillin, $10 \mu \mathrm{g} / \mathrm{kg}$ for oxytetracycline and erythromycin, $15 \mu \mathrm{g} / \mathrm{kg}$ for cloxacillin, and $50 \mu \mathrm{g} / \mathrm{kg}$ for ciprofloxacin and enrofloxacin.

\section{Analysis of Cheese Samples}

Tronchón cheese analysis was carried out with 2 cheeses of each batch being analyzed at the different ripening times $(0,30$, and $60 \mathrm{~d})$. The $\mathrm{pH}$ of the cheese was measured in triplicate using a $\mathrm{pH}$ meter (model Basic 20, Crison Instruments) with a penetration probe (model 5232, Crison Instruments). The physicochemical characteristics were analyzed in duplicate. The chemical composition of the cheeses (i.e., DM, fat, protein, and salt contents) was determined using a FoodScan Analyzer (Foss). The calibration curve had previously been developed for matured goat cheeses.

The total contents of free amino acids (FAA) and free fatty acids (FFA) were used as indicators of proteolytic and lipolytic activities in the cheeses during maturation. The FAA concentration ( $\mathrm{mg}$ of leucine/g of cheese) was analyzed using the Cd-ninhydrin reagent as reported by Folkertsma and Fox (1992). Level of FFA (mEq/100 $\mathrm{g}$ of fat) was determined by titration using $\mathrm{KOH}$ ethanolic solution according to Nuñez et al. (1986).

Color and textural properties were assessed in triplicate at room temperature $\left(20 \pm 1^{\circ} \mathrm{C}\right)$ using cylindrical samples taken $2 \mathrm{~cm}$ deep below the rind of the cheese (1-cm height $\times 2$-cm diameter). The cheese color was assessed by CIELAB color space and determined using a spectrocolorimeter (Minolta CM-3600D, Minolta, Tokyo, Japan). The CIELAB color space expresses color as 3 numerical parameters: lightness $\left(\mathbf{L}^{*}\right)$ has ranges between 0 and 100, redness $\left(\mathbf{a}^{*}\right)$ represents red or green color (positive: red; negative: green), and yellowness (b*) stands for color ranging from yellow to blue (positive: yellow; negative: blue). The color coordinates CIE
$\mathrm{L}^{*}, \mathrm{a}^{*}$, and $\mathrm{b}^{*}$ were obtained using observer $10^{\circ}$ and illuminant D65. From these coordinates, color differences $\left(\Delta \mathbf{E}^{*}{ }_{\mathrm{ab}}\right)$ of the cheeses made from milk spiked with antibiotics compared with control cheeses were determined using the equation proposed by Bodart et al. (2008):

$$
\Delta \mathrm{E}_{\mathrm{ab}}^{*}=\sqrt{\left(\Delta \mathrm{L}^{*}\right)^{2}+\left(\Delta \mathrm{a}^{*}\right)^{2}+\left(\Delta \mathrm{b}^{*}\right)^{2}},
$$

where $\Delta \mathrm{E}^{*}{ }_{\mathrm{ab}}$ is the color difference using the CIELab coordinates $\Delta \mathrm{L}^{*}, \Delta \mathrm{a}^{*}$, and $\Delta \mathrm{b}^{*}$, which are the differences between the 2 samples in $\mathrm{L}^{*}, \mathrm{a}^{*}$, and $\mathrm{b}^{*}$, respectively. The perception of the color difference $\Delta \mathrm{E}^{*}$ varied according to the observed color and the sensitivity of the human eye: $\Delta \mathrm{E}^{*}<1$ color differences could not be detected by the human eye, $1<\Delta \mathrm{E}^{*}<3$ minor color differences could be detected by the human eye, and $\Delta \mathrm{E}^{*}>3$ color differences could be detected by the human eye.

A texture profile analysis was carried out using a TA-XT Plus Texture Analyzer (Stable Micro Systems, Surrey, UK). A plunger with a diameter of $45 \mathrm{~mm}$ was used. The cheese sample was compressed to $50 \%$ of its height at a constant deformation rate of $1 \mathrm{~mm} / \mathrm{s}$, leaving $5 \mathrm{~s}$ between the first and second compressions. The following texture parameters were measured from the force-deformation curve: hardness (N), adhesiveness $(\mathrm{N} \cdot \mathrm{s})$, cohesiveness, springiness, and chewiness $(\mathrm{N})$.

\section{Sensory Evaluation}

Sensory evaluation of the cheeses at $60 \mathrm{~d}$ of ripening was carried out by 100 untrained consumers. Representative wedges $(0.5 \mathrm{~cm}$ thick) of the $\mathrm{AF}$ and $\mathrm{SM}$ cheeses were prepared at room temperature, coded with random 3-digit numbers, and presented individually to the tasters. Consumer acceptance testing was carried out using a 9 -point hedonic scale $(1=$ dislike very much to 9 = like very much) according to ISO method 4121:2003 (ISO, 2003). The attributes considered were appearance, odor, color, texture, and overall preference. Because the cheeses with antibiotics could contain residues, the taste analysis was considered inopportune. The results are depicted as spider web diagrams.

\section{Statistical Analyses}

The data were analyzed using Statgraphics Centurion XVI.II software (Statpoint Technologies Inc., The Plains, VA). When significant $(P<0.05)$ differences were found, means were separated by the least significance difference test. A 1-way ANOVA was applied to evaluate the relationship between the acidification time 
during cheese-making and the presence of the antibiotic in milk. Also, this analysis was used to evaluate the sensorial attributes of the cheeses. Furthermore, for each drug, the differences between cheeses from milk spiked with antibiotics and control cheeses were evaluated by means of a 2-way ANOVA applied to each of the parameters studied, considering as factors the antibiotic concentration (AF or SM cheeses) and the ripening time $(0,30$, or $60 \mathrm{~d})$ and their interaction.

\section{RESULTS AND DISCUSSION}

\section{Antibiotic Residues in Goat Milk Cheeses}

Table 1 displays the residual amounts of antibiotics found in the SM cheeses at 0, 30, and $60 \mathrm{~d}$ of ripening. As shown in this table, variable concentrations of antibiotics were detected in all the cheeses from spiked goat milk before maturation $(0 \mathrm{~d})$, although such residues could not be quantified in the case of amoxicillin, the residual concentration of which was below the limit of quantification of the LC method $(\leq 2 \mu \mathrm{g} / \mathrm{kg})$.

The transfer of the different antibiotics from milk to cheese was calculated as a retention rate percentage (Figure 1), taking into account the residual amount of antibiotic retained in the cheeses before maturation $(0$ d) and the cheese yield obtained in each cheese-making trial, which ranged from 13.2 to $17.7 \mathrm{~kg}$ of cheese/100 $\mathrm{kg}$ of milk. The retention rates for $\beta$-lactam antibiotics and erythromycin were much lower than those obtained for quinolones and oxytetracycline, the residues of which in the fresh cheeses $(0 \mathrm{~d})$ were 2.7 to 4.3 times higher than the initial drug concentration in raw goat milk, evidencing the elevated susceptibility of these substances to be retained in the cheese matrix.

The higher or lower transfer of antibiotics from milk to cheese could be related to the solubility character- istics of these substances (Giraldo et al., 2017). Thus, the high water solubility of $\beta$-lactams and erythromycin with dissociation constant $\left(\mathrm{pK}_{a}\right)$ values ranging from 2.6 to 8.8 (Reeves, 2011; Giguère, 2013) could explain the lower retention rates obtained for those substances that are mostly transferred from the cheese to the whey during the draining-off. On the contrary, the high fat affinity of quinolones and oxytetracycline (Giguère, 2013) favors their trapping in the cheese matrix, containing high concentrations of fat and protein with which oxytetracycline can also interact to form stable chelates (Lees and Toutain, 2011); this likely explains the high retention rate $(68 \%)$ calculated for this substance.

In all cases, the antibiotic concentration in the fresh cheeses decreases during maturation (Table 1). Thus, $\beta$-lactam drugs and erythromycin were not detected in cheeses ripened for $30 \mathrm{~d}$. However, quinolones and oxytetracycline were detected even after a period of $60 \mathrm{~d}$, although the residual concentrations of oxytetracycline in ripened cheeses were $95 \%$ lower than those at the beginning of maturation, possibly due to the lower stability of this substance under refrigerated conditions (Roca, 2008). Instead, quinolones were more stable, showing a lower reduction rate along maturation (30-45\%). This also implies a higher concentration of these drugs in the final products, making it necessary to assess their risk for consumer health. Also, the transfer of antibiotic residues from cheese to whey (Giraldo et al., 2017; Gajda et al., 2018) could have negative implications for human, animal, and environmental safety because this by-product is used in the manufacture of foodstuffs for human consumption, animal feeding, and agricultural applications, among other uses (Carvalho et al., 2013).

Our results are consistent with those reported by other authors assessing the transfer of antibiotics from milk to cheese, such as Giraldo et al. (2017), who evaluated the antimicrobial activity of the whey from

Table 1. Antibiotic concentration $(\mu \mathrm{g} / \mathrm{kg})$ in Tronchón cheese made from goat milk spiked with antibiotics at European Union maximum residue limit (EU MRL) concentration during ripening (mean $\pm \mathrm{SD}$ )

\begin{tabular}{lcccc}
\hline & & \multicolumn{3}{c}{ Ripening time $(\mathrm{d})$} \\
\cline { 3 - 5 } Antibiotic & $\begin{array}{c}\text { EU MRL } \\
(\mu \mathrm{g} / \mathrm{kg})\end{array}$ & 0 & 30 & 60 \\
\hline Amoxicillin & 4 & $\operatorname{Tr}^{2}$ & $\mathrm{ND}^{3}$ & $\mathrm{ND}$ \\
Benzylpenicillin & 4 & $4.8 \pm 1.3$ & $\mathrm{ND}$ & $\mathrm{ND}$ \\
Cloxacillin & 30 & $28.8 \pm 1.7$ & $\mathrm{ND}$ & $\mathrm{ND}$ \\
Erythromycin & 40 & $21.8 \pm 1.0$ & $309.4 \pm 19.6$ & $252.9 \pm 23.7$ \\
Ciprofloxacin & $100^{4}$ & $362.5 \pm 36.5$ & $153.8 \pm 0.6$ & $147.5 \pm 11.5$ \\
Enrofloxacin & $100^{4}$ & $268.7 \pm 55.7$ & $140.6 \pm 15.4$ & $20.0 \pm 5.7$ \\
Oxytetracycline & 100 & $432.3 \pm 31.9$ &
\end{tabular}

${ }^{1}$ European Union maximum residue limit in raw milk (European Union, 2010).

${ }^{2}$ Traces (limit of detection $<$ result $<$ limit of quantification).

${ }^{3}$ Not detected (result $<$ limit of detection).

${ }^{4} \mathrm{Sum}$ of enrofloxacin and ciprofloxacin. 


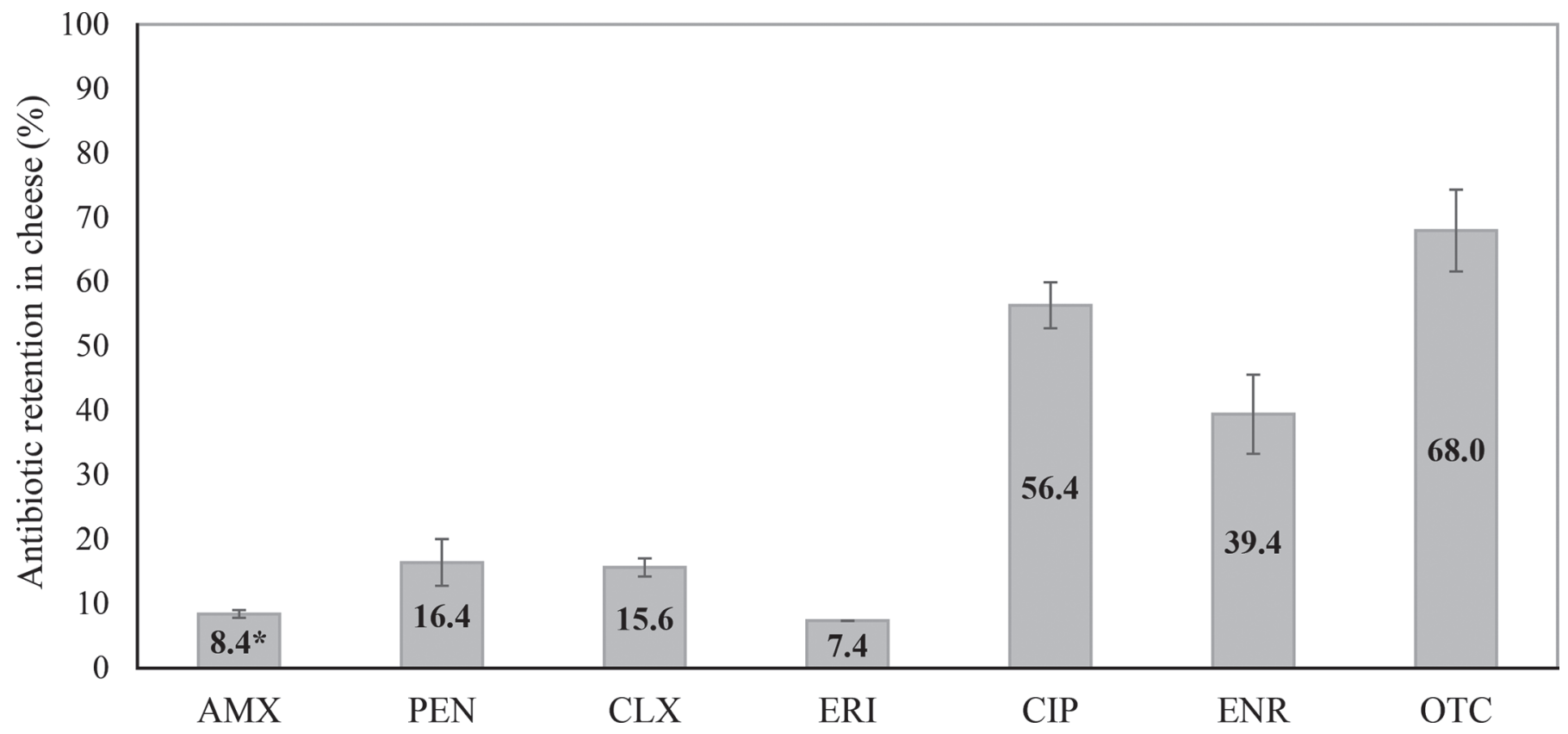

Figure 1. Retention rate (\%; mean $\pm \mathrm{SD})$ of antibiotic Tronchón cheese before ripening made from goat milk spiked with antibiotics at European Union maximum residue limits concentration. AMX = amoxicillin, PEN = benzylpenicillin, CLX = cloxacillin, ERI = erythromycin, $\mathrm{CIP}=$ ciprofloxacin, ENR = enrofloxacin, OTC = oxytetracycline. Asterisk $(*)$ indicates that retention was calculated considering the equivalent value to the limit of quantification (amoxicillin: $2 \mu \mathrm{g} / \mathrm{kg}$ ).

contaminated milk, or Cabizza et al. (2017) and Gajda et al. (2018), who investigated the transfer of oxytetracycline from sheep and cow milk to cheese, respectively. The oxytetracycline retention in cheese at the beginning of the ripening process $(0 \mathrm{~d})$ is similar to that shown by Cabizza et al. (2017). However, the evolution of the content of this antibiotic during maturation is different from that observed in the present study. The aforementioned authors observed a much lower degradation of the antibiotic at the end of maturation. This greater denaturation of the antibiotic could be related to the type of milk (sheep vs. goat) and the difference in production-related factors (acidification, ripening time and conditions, surface mold growth, and so on)

\section{Effect of the Antibiotics on Cheese-Making}

The cheese-making process was unaffected by the presence of $\beta$-lactams and quinolones at safety levels in raw goat milk. However, the time required for cheese production using milk containing admissible amounts of erythromycin and oxytetracycline (40 and $100 \mu \mathrm{g} /$ $\mathrm{kg}$, respectively) increased $(P=0.003$ and $P=0.013$, respectively). As shown in Figure 2, the kinetic of acidification of the cheeses during cheese production was considerably affected by the presence of these antibiotics, requiring additional time to reach the final $\mathrm{pH}$
$(5.30 \pm 0.05)$ in the cheeses made from milk containing erythromycin (122 $\pm 29 \mathrm{~min})$ and oxytetracycline (108 $\pm 25 \mathrm{~min})$ with respect to the control cheeses. This suggests that the activity of the starter cultures was strongly inhibited by the presence of these antibiotics, leading to a lower acidification rate than in the control cheeses, especially for erythromycin, which also increased $(P=0.006)$ the heating and stirring time $(25 \pm 5 \mathrm{~min})$ before the draining-off and molding of the curd (Figure 2A). Similarly, Cabizza et al. (2017, 2018) observed delays, ranging from 60 to $78 \mathrm{~min}$, in the acidification process during ewe cheese manufacture from milk with oxytetracycline at safety level $(100 \mu \mathrm{g} /$ $\mathrm{kg})$. Moreover, a concentration below MRL for erythromycin $(16 \mu \mathrm{g} / \mathrm{L})$ reported by Katla et al. (2001) reduced by $50 \%$ the activity of Streptococcus spp. isolated from dairy products (yogurt, sour cream, fermented milk, whey, and cheese) and commercial starter cultures.

As expected, the results herein suggest that admissible amounts of some antibiotic residues in milk could interfere in the metabolism of the microbiota present in the initial stages of the production of ripened cheese. This could also affect its capacity to develop the complex biochemical processes necessary during maturation, and the quality characteristics of the mature cheeses could therefore be affected. On the other hand, low activity of the starter culture could result 
A)
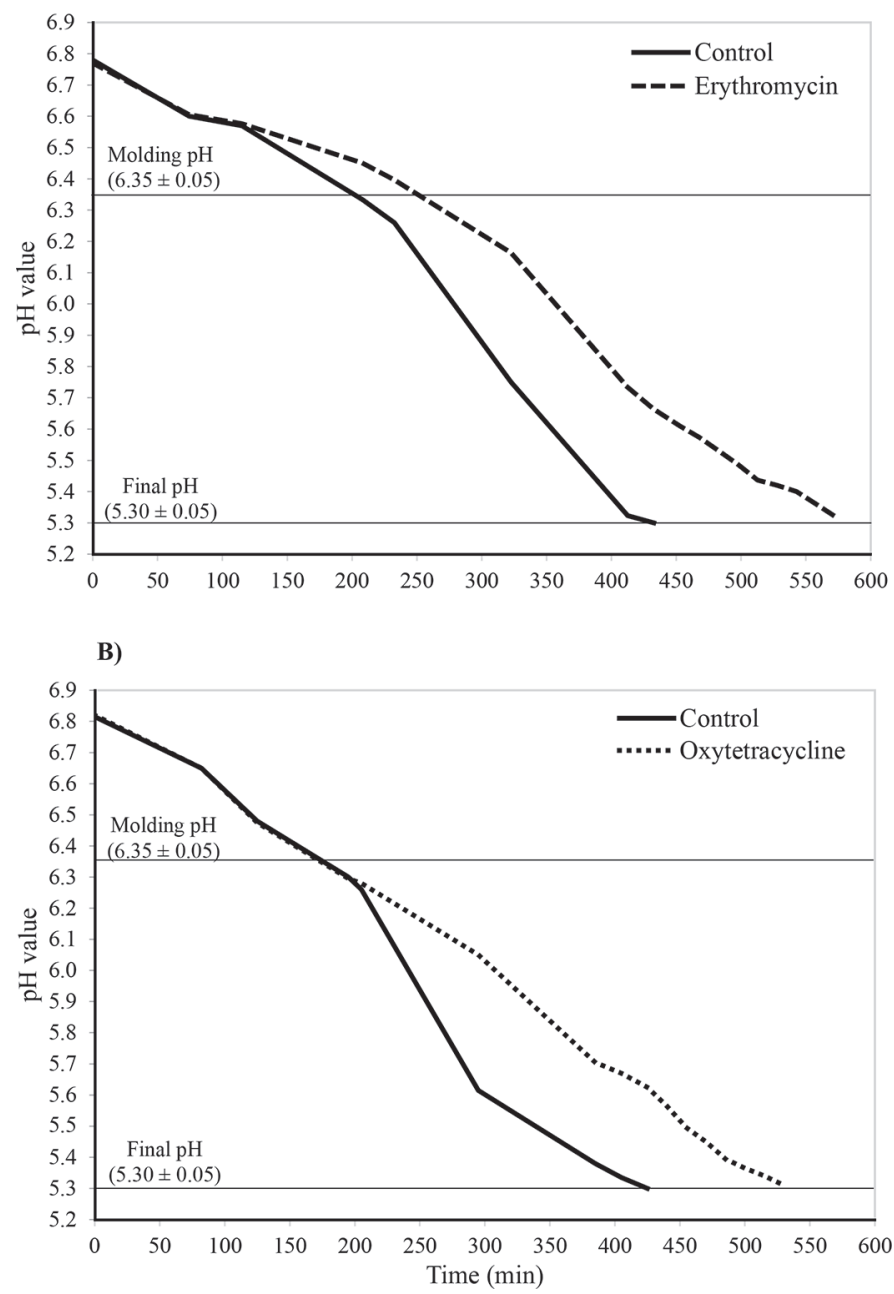

Figure 2. Kinetic acidification of the cheeses made from goat milk spiked with antibiotic during cheese-making: (A) erythromycin; (B) oxytetracycline.

in more favorable environmental growth conditions for undesirable bacteria, such as coliforms (Cabizza et al., 2018), during cheese-making, which could affect the microbiological safety of the cheeses (Choi et al., 2016).

\section{Physicochemical Parameters of the Cheeses}

Table 2 summarizes the quality characteristics of the experimental Tronchón cheeses according to the factors of variation "antibiotic concentration" and "ripening time" separately given that the interaction between the 2 factors considered was not significant $(P>0.05)$. The use of raw goat milk spiked with antibiotics at EU MRL concentration did not affect the physicochemical characteristics of the cheeses $(P>0.05)$, which presented values similar to those of their respective references. Nevertheless, the ripening time presented a significant effect on all the physicochemical parameters of the cheeses (Table 2), although both types of cheese (AF and $\mathrm{SM}$ ) evolved in a similar way during maturation (nonsignificant interaction).

As shown in Table 2, all the variables evaluated in the experimental cheeses were affected by the ripening time $(P<0.05)$. In general, the $\mathrm{pH}$ of the cheeses diminished in the first $30 \mathrm{~d}$ of maturation and remained invariable until the end of the ripening period, showing a trend similar to that reported by Salvador et al. (2014) but being higher than that obtained in other Spanish goat cheeses such as Ibores (pH 4.88; Delgado et al., 2011) and Majorero (pH 5.03; Fresno and Álvarez, 2012). On the whole, as ripening progressed the DM, fat, protein, and $\mathrm{NaCl}$ content of the cheeses increased, basically due to the loss of water content during maturation. In any case, the concentration of the main cheese components was similar to that indicated by other authors in different goat milk cheeses (Freitas and Malcata, 2000; Ferrandini et al., 2011; Salvador et al., 2014). Slight differences mainly related to the fat content of cheeses were possibly related to other factors such as animal breed, lactation period, and feeding as well as the specific cheese-making process applied in each type of cheese (Chilliard et al., 2003; Lucas et al., 2006; Park, 2017).

\section{Proteolytic and Lipolytic Activities in the Cheeses}

Proteolysis and lipolysis play a major role in the development of texture and flavor in most cheese varieties during ripening, directly contributing to flavor via formation of peptides and FAA (Fenelon et al., 2000) as well as FFA from the lipolysis of triglycerides (Collins et al., 2003). The effect of the antibiotics on the proteolytic and lipolytic activities in the cheeses is presented in Table 3. Proteolytic activity in the SM cheeses did not seem to be affected by the presence of antibiotics $(P>0.05)$, showing FAA concentrations similar to those of their respective references. However, a lower content of FFA in the SM cheeses with amoxicillin $(P$ $=0.0001)$ and cloxacillin $(P=0.01)$ was observed, suggesting a reduced biochemical activity in these cheeses, possibly due to inhibitory action of these $\beta$-lactams on the metabolism of the lipolytic bacteria (Berruga et al., 2016), which could adversely affect their typical textural and flavor properties (Collins et al., 2003; Thierry et al., 2017). The other drugs studied did not affect this metabolic pathway in the SM cheeses, which presented FFA concentrations similar to those of their control counterparts $(P>0.05)$. On the other hand, 
FAA and FFA concentrations of the cheeses increased, as expected, throughout the ripening period (Table 3), and no significant interactions between the 2 factors considered were found in any case. In general, the FAA content in the experimental cheeses was on the order of those reported by other authors for cheeses ripened for $60 \mathrm{~d}$ (Juan et al., 2016), and the FFA content showed a trend similar to the data presented by Buffa et al. (2001) in mature cheese made from raw goat milk.

\section{Color Evaluation of the Cheeses}

As shown in Table 4, the color parameters evaluated in the cheeses were affected by the presence of some antibiotics in goat milk. Thus, a lower brightness $\left(\mathrm{L}^{*}\right)$ value $(P=0.0001)$ was obtained in the SM cheeses containing ciprofloxacin. The redness $\left(\mathrm{a}^{*}\right)$ presented low values in the cheeses from milk spiked with benzylpeni- cillin $(P=0.03)$, cloxacillin $(P=0.01)$, and erythromycin $(P=0.01)$ compared with control cheese. Similarly, the yellowness $\left(\mathrm{b}^{*}\right)$ value was lower $(P=0.007)$ in the SM cheeses with oxytetracycline. However, differences found instrumentally could not be detected by consumers, as the calculated $\Delta \mathrm{E}$ value (Bodart et al., 2008) ranged from 0.88 to 2.02 for the different antibiotics considered.

Regarding the effect of ripening on the color properties of the cheeses (Table 4), a significant reduction in $\mathrm{L}^{*}$ and the $\mathrm{a}^{*}$ coordinate were observed, whereas the $b^{*}$ coordinate value increased over time, possibly related to proteolysis and browning reactions that occur during maturation (Carreira et al., 2002; Tejada et al., 2007). A significant interaction (antibiotic concentration $\times$ ripening time, $P<0.001)$ was found for the $\mathrm{a}^{*}$ coordinate, which was only significantly lower in SM cheeses with cloxacillin at $60 \mathrm{~d}$ of ripening.

Table 2. Effect of antibiotic concentration and ripening time on the physicochemical characteristics of Tronchón cheese made from goat milk

\begin{tabular}{|c|c|c|c|c|c|c|c|c|}
\hline Antibiotic & Parameter & \multicolumn{2}{|c|}{ Antibiotic concentration ${ }^{1}$} & SEM & \multicolumn{3}{|c|}{ Ripening time (d) } & SEM \\
\hline \multirow{3}{*}{ Amoxicillin } & $\mathrm{DM}(\%)$ & 59.9 & 59.3 & 0.28 & $57.4^{\mathrm{a}}$ & $59.6^{\mathrm{b}}$ & $61.9^{\mathrm{c}}$ & 0.34 \\
\hline & Fat $(\%)$ & 32.6 & 32.6 & 0.23 & $31.9^{\mathrm{a}}$ & $32.4^{\mathrm{b}}$ & $33.5^{\mathrm{b}}$ & 0.29 \\
\hline & Protein $(\%)$ & 22.2 & 22.0 & 0.10 & $20.7^{\mathrm{a}}$ & $21.9^{\mathrm{b}}$ & $23.7^{\mathrm{c}}$ & 0.13 \\
\hline \multirow{4}{*}{ Benzylpenicillin } & $\mathrm{DM}(\%)$ & 60.9 & 61.1 & 0.12 & $54.0^{\mathrm{a}}$ & $61.8^{\mathrm{b}}$ & $67.2^{\mathrm{c}}$ & 0.15 \\
\hline & Fat $(\%)$ & 32.4 & 33.1 & 0.25 & $28.9^{\mathrm{a}}$ & $33.3^{\mathrm{b}}$ & $35.9^{\mathrm{c}}$ & 0.30 \\
\hline & Protein (\%) & 23.7 & 23.6 & 0.18 & $20.8^{\mathrm{a}}$ & $23.9^{\mathrm{b}}$ & $26.2^{\mathrm{c}}$ & 0.22 \\
\hline & $\mathrm{NaCl}(\%)$ & 2.03 & 2.08 & 0.019 & $1.65^{\mathrm{a}}$ & $2.19^{\mathrm{b}}$ & $2.32^{\mathrm{c}}$ & 0.022 \\
\hline \multirow[t]{3}{*}{ Cloxacillin } & $\mathrm{pH}$ & 5.31 & 5.32 & 0.013 & $5.36^{\mathrm{b}}$ & $5.29^{\mathrm{a}}$ & $5.30^{\mathrm{a}}$ & 0.016 \\
\hline & $\mathrm{DM}(\%)$ & 59.8 & 59.2 & 0.25 & $57.5^{\mathrm{a}}$ & $59.2^{\mathrm{b}}$ & $61.7^{\mathrm{c}}$ & 0.30 \\
\hline & Fat $(\%)$ & 32.3 & 32.0 & 0.18 & $31.7^{\mathrm{a}}$ & $32.1^{\mathrm{a}}$ & $32.8^{\mathrm{b}}$ & 0.22 \\
\hline \multirow{2}{*}{ Erythromycin } & Protein (\%) & 22.7 & 22.9 & 0.23 & $20.0^{\mathrm{a}}$ & $23.4^{\mathrm{b}}$ & $25.2^{\mathrm{c}}$ & 0.29 \\
\hline & $\mathrm{NaCl}(\%)$ & 2.17 & 2.12 & 0.026 & $1.77^{\mathrm{a}}$ & $2.21^{\mathrm{b}}$ & $2.45^{\mathrm{c}}$ & 0.032 \\
\hline \multirow[t]{5}{*}{ Ciprofloxacin } & $\mathrm{pH}$ & 5.19 & 5.21 & 0.022 & $5.26^{\mathrm{b}}$ & $5.15^{\mathrm{a}}$ & $5.19^{\mathrm{ab}}$ & 0.027 \\
\hline & $\mathrm{DM}(\%)$ & 62.1 & 62.6 & 0.18 & $54.6^{\mathrm{a}}$ & $65.0^{\mathrm{b}}$ & $67.4^{\mathrm{c}}$ & 0.22 \\
\hline & Fat $(\%)$ & 34.8 & 34.4 & 0.28 & $30.1^{\mathrm{a}}$ & $36.0^{\mathrm{b}}$ & $37.7^{\mathrm{c}}$ & 0.34 \\
\hline & Protein (\%) & 23.1 & 23.6 & 0.21 & $19.7^{\mathrm{a}}$ & $24.4^{\mathrm{b}}$ & $25.9^{\mathrm{c}}$ & 0.26 \\
\hline & $\mathrm{NaCl}(\%)$ & 1.93 & 1.93 & 0.017 & $1.76^{\mathrm{a}}$ & $1.94^{\mathrm{b}}$ & $2.08^{\mathrm{c}}$ & 0.021 \\
\hline \multirow[t]{5}{*}{ Enrofloxacin } & $\mathrm{pH}$ & 5.22 & 5.21 & 0.018 & $5.26^{\mathrm{b}}$ & $5.22^{\mathrm{ab}}$ & $5.17^{\mathrm{a}}$ & 0.022 \\
\hline & $\mathrm{DM}(\%)$ & 63.3 & 63.5 & 0.22 & $56.5^{\mathrm{a}}$ & $66.6^{\mathrm{b}}$ & $67.1^{\mathrm{b}}$ & 0.27 \\
\hline & Fat $(\%)$ & 35.0 & 35.1 & 0.17 & $31.1^{\mathrm{a}}$ & $37.0^{\mathrm{b}}$ & $37.1^{\mathrm{b}}$ & 0.21 \\
\hline & Protein (\%) & 23.8 & 24.2 & 0.14 & $20.8^{\mathrm{a}}$ & $25.5^{\mathrm{b}}$ & $25.7^{\mathrm{b}}$ & 0.17 \\
\hline & $\mathrm{NaCl}(\%)$ & 1.86 & 1.80 & 0.023 & $1.71^{\mathrm{a}}$ & $1.77^{\mathrm{a}}$ & $2.01^{\mathrm{b}}$ & 0.027 \\
\hline \multirow{2}{*}{ Oxytetracycline } & $\mathrm{pH}$ & 5.23 & 5.19 & 0.037 & $5.33^{\mathrm{b}}$ & $5.11^{\mathrm{a}}$ & $5.19^{\mathrm{a}}$ & 0.046 \\
\hline & $\mathrm{DM}(\%)$ & 62.0 & 61.7 & 0.31 & $54.2^{\mathrm{a}}$ & $64.1^{\mathrm{b}}$ & $67.2^{\mathrm{c}}$ & 0.38 \\
\hline
\end{tabular}

\footnotetext{
${ }^{\mathrm{a}-\mathrm{c}}$ Superscript letters within a row for factor indicate significant differences $(P<0.05)$.
}

${ }^{1} \mathrm{AF}=$ antibiotic free; $\mathrm{SM}=$ spiked milk. 
Table 3. Effect of antibiotic concentration and ripening time on the proteolytic (FAA) and lipolytic (FFA) activities in Tronchón cheese made from goat milk

\begin{tabular}{|c|c|c|c|c|c|c|c|c|}
\hline \multirow[b]{2}{*}{ Antibiotic } & \multirow[b]{2}{*}{ Parameter $^{1}$} & \multicolumn{2}{|c|}{ Antibiotic concentration $^{2}$} & \multirow[b]{2}{*}{ SEM } & \multicolumn{3}{|c|}{ Ripening time (d) } & \multirow[b]{2}{*}{ SEM } \\
\hline & & $\begin{array}{c}\mathrm{AF} \\
(\mathrm{n}=12)\end{array}$ & $\begin{array}{c}\mathrm{SM} \\
(\mathrm{n}=12)\end{array}$ & & $\begin{array}{c}0 \\
(\mathrm{n}=8)\end{array}$ & $\begin{array}{c}30 \\
(\mathrm{n}=8)\end{array}$ & $\begin{array}{c}60 \\
(\mathrm{n}=8)\end{array}$ & \\
\hline Amoxicillin & FFA & $2.67^{\mathrm{b}}$ & $2.21^{\mathrm{a}}$ & 0.063 & $1.65^{\mathrm{a}}$ & $2.45^{\mathrm{b}}$ & $3.22^{\mathrm{c}}$ & 0.077 \\
\hline \multirow[t]{2}{*}{ Benzylpenicillin } & FAA & 1.74 & 1.70 & 0.031 & $0.70^{\mathrm{a}}$ & $2.10^{\mathrm{b}}$ & $2.36^{\mathrm{c}}$ & 0.037 \\
\hline & FFA & 2.45 & 2.48 & 0.071 & $1.90^{\mathrm{a}}$ & $2.27^{\mathrm{b}}$ & $3.22^{\mathrm{c}}$ & 0.089 \\
\hline \multirow[t]{2}{*}{ Erythromycin } & FAA & 2.28 & 2.12 & 0.060 & $0.68^{\mathrm{a}}$ & $2.26^{\mathrm{b}}$ & $3.65^{\mathrm{c}}$ & 0.073 \\
\hline & FFA & 2.80 & 2.90 & 0.162 & $1.96^{\mathrm{a}}$ & $2.95^{\mathrm{b}}$ & $3.65^{\mathrm{c}}$ & 0.198 \\
\hline \multirow[t]{2}{*}{ Ciprofloxacin } & FAA & 2.26 & 2.28 & 0.045 & $1.21^{\mathrm{a}}$ & $2.32^{\mathrm{b}}$ & $3.28^{\mathrm{c}}$ & 0.055 \\
\hline & FFA & 3.12 & 2.96 & 0.053 & $2.44^{\mathrm{a}}$ & $2.89^{\mathrm{b}}$ & $3.80^{\mathrm{c}}$ & 0.065 \\
\hline \multirow[t]{2}{*}{ Enrofloxacin } & FAA & 2.41 & 2.34 & 0.082 & $1.13^{\mathrm{a}}$ & $2.80^{\mathrm{b}}$ & $3.19^{c}$ & 0.101 \\
\hline & FFA & 3.01 & 3.03 & 0.069 & $2.53^{\mathrm{a}}$ & $2.85^{\mathrm{b}}$ & $3.66^{\mathrm{c}}$ & 0.084 \\
\hline Oxytetracycline & FAA & 1.94 & 1.99 & 0.090 & $1.20^{\mathrm{a}}$ & $2.07^{\mathrm{b}}$ & $2.62^{\mathrm{c}}$ & 0.110 \\
\hline
\end{tabular}

${ }^{\mathrm{a}-\mathrm{c}}$ Superscript letters within a row for factor indicate significant differences $(P<0.05)$.

${ }^{1} \mathrm{FAA}=$ free $\mathrm{AA}(\mathrm{mg}$ of leucine $/ \mathrm{g}$ of cheese $) ; \mathrm{FFA}=$ free fatty acids $(\mathrm{mEq} / 100 \mathrm{~g}$ of fat).

${ }^{2} \mathrm{AF}=$ antibiotic free; $\mathrm{SM}=$ spiked milk.

A similar trend in color parameters was reported by Buffa et al. (2001) and Salvador et al. (2014), who analyzed goat cheese under similar conditions. The results obtained also agreed with those reported by Fresno and Álvarez (2012) in Majorero goat cheese ripened for a 60-d period (L*: 84.83; a*: -2.28; b*: 11.89).

\section{Textural Properties of the Cheeses}

The effect of the antibiotics on the textural properties of the Tronchón cheeses is shown in Table 5 . Most of the drugs used in this study did not affect the texture profile of the cheeses, showing values similar to

Table 4. Effect of antibiotic concentration and ripening time on the color coordinates of Tronchón cheese made from goat milk

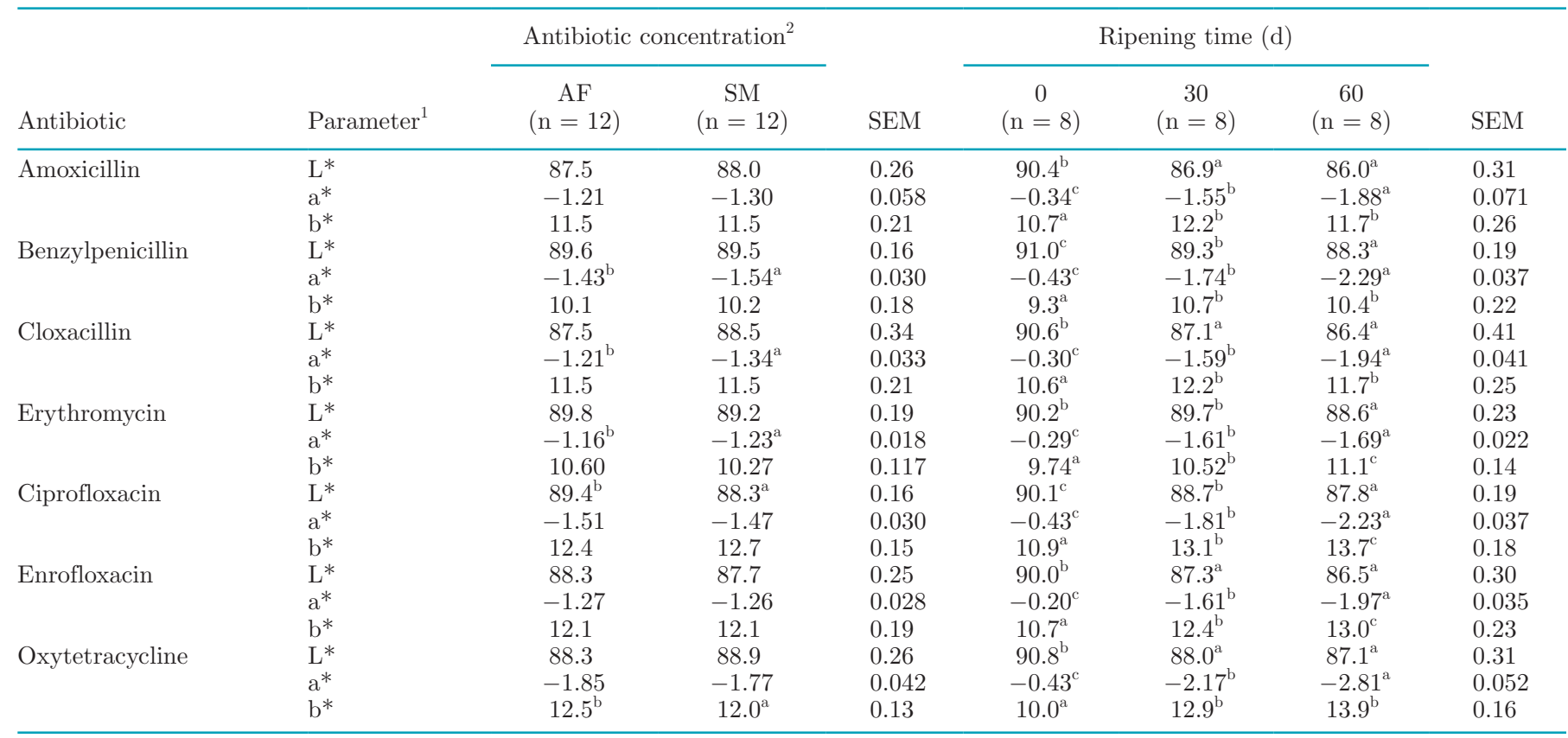

\footnotetext{
${ }^{\mathrm{a}-\mathrm{c}}$ Superscript letters within a row for factor indicate significant differences $(P<0.05)$.
}

${ }^{1}$ The CIELAB color space expresses color as 3 numerical parameters: lightness $\left(\mathrm{L}^{*}\right)$ has ranges between 0 and 100 , redness $\left(\mathrm{a}^{*}\right)$ represents red or green color (positive: red; negative: green), and yellowness (b*) stands for color ranging from yellow to blue (positive: yellow; negative: blue).

${ }^{2} \mathrm{AF}=$ antibiotic free; $\mathrm{SM}=$ spiked milk. 
those obtained for the $\mathrm{AF}$ cheeses used as a reference. The lower hardness $(P=0.0002)$ and chewiness $(P=$ $0.0025)$ values observed in the cheeses from milk containing oxytetracycline, which also presented a higher cohesiveness value $(P=0.007)$, should be highlighted. These differences could be related to the interaction between oxytetracycline and the $\mathrm{Ca}^{2+}$ ion (Arias et al., 2007) forming stable bonds, which could affect the conformation of the casein network (Everett and Auty, 2008), leading, consequently, to changes in textural properties of cheeses (e.g., hardness).

During ripening, the cheese samples became significantly harder and more adhesive, whereas the springiness, cohesiveness, and chewiness decreased significantly in the presence of most of the antibiotics evaluated (Table 5). In general, these changes are consistent with previous results under similar conditions (Delgado et al., 2011; Salvador et al., 2014), although values vary according to the type of cheese.

In cheeses made from milk spiked with amoxicillin and cloxacillin, however, hardness evolved in an inverse way during maturation, showing a trend similar to that indicated by Chen et al. (2010) in cheese from goat milk. These results could be related to the higher SCC of goat milk used for cheese production $\left(1.6 \times 10^{6}\right.$ cells / $\mathrm{mL}$ ) detected in a more advanced lactation stage than for the other antibiotics assessed. In addition to lower hardness values, the SM cheeses with amoxicillin and cloxacillin presented higher moisture and FAA contents (Tables 2 and 3), characteristics found by other authors (Revilla et al., 2007; Merin et al., 2008; Chen et al., 2010) in cheeses from milk with high SCC.

Table 5. Effect of antibiotic concentration and ripening time on the texture profile of Tronchón cheese made from goat milk

\begin{tabular}{|c|c|c|c|c|c|c|c|c|}
\hline \multirow[b]{2}{*}{ Antibiotic } & \multirow[b]{2}{*}{ Parameter } & \multicolumn{2}{|c|}{ Antibiotic concentration $^{1}$} & \multirow[b]{2}{*}{$\mathrm{SEM}^{2}$} & \multicolumn{3}{|c|}{ Ripening time (d) } & \multirow[b]{2}{*}{ SEM } \\
\hline & & $\begin{array}{c}\mathrm{AF} \\
(\mathrm{n}=12)\end{array}$ & $\begin{array}{c}\text { SM } \\
(\mathrm{n}=12)\end{array}$ & & $\begin{array}{c}0 \\
(\mathrm{n}=8)\end{array}$ & $\begin{array}{c}30 \\
(\mathrm{n}=8)\end{array}$ & $\begin{array}{c}60 \\
(\mathrm{n}=8)\end{array}$ & \\
\hline \multirow[t]{5}{*}{ Amoxicillin } & Hardness (N) & 20.8 & 20.9 & 0.99 & $28.0^{\mathrm{b}}$ & $18.6^{\mathrm{a}}$ & $15.9^{\mathrm{a}}$ & 1.22 \\
\hline & Adhesiveness $(\mathrm{N} \cdot \mathrm{s})$ & -0.93 & -0.96 & 0.047 & $-0.61^{\mathrm{b}}$ & $-1.09^{\mathrm{a}}$ & $-1.13^{\mathrm{a}}$ & 0.057 \\
\hline & Springiness & 0.63 & 0.61 & 0.010 & $0.81^{\mathrm{c}}$ & $0.57^{\mathrm{b}}$ & $0.47^{\mathrm{a}}$ & 0.011 \\
\hline & Cohesiveness & 0.43 & 0.42 & 0.005 & $0.67^{\mathrm{c}}$ & $0.33^{\mathrm{b}}$ & $0.28^{\mathrm{a}}$ & 0.006 \\
\hline & Chewiness (N) & 7.0 & 6.9 & 0.36 & $15.3^{\mathrm{c}}$ & $3.5^{\mathrm{b}}$ & $2.1^{\mathrm{a}}$ & 0.45 \\
\hline \multirow[t]{5}{*}{ Benzylpenicillin } & Hardness (N) & 26.5 & 24.7 & 0.98 & $24.2^{\mathrm{a}}$ & $23.0^{\mathrm{a}}$ & $29.7^{\mathrm{b}}$ & 1.20 \\
\hline & Adhesiveness $(\mathrm{N} \cdot \mathrm{s})$ & -1.25 & -1.19 & 0.085 & $-0.47^{\mathrm{b}}$ & $-1.53^{\mathrm{a}}$ & $-1.66^{\mathrm{a}}$ & 0.103 \\
\hline & Springiness & 0.62 & 0.62 & 0.014 & $0.83^{\mathrm{c}}$ & $0.48^{\mathrm{a}}$ & $0.56^{\mathrm{b}}$ & 0.017 \\
\hline & Cohesiveness & 0.40 & 0.44 & 0.016 & $0.73^{\mathrm{c}}$ & $0.30^{\mathrm{b}}$ & $0.23^{\mathrm{a}}$ & 0.019 \\
\hline & Chewiness (N) & 7.1 & 7.2 & 0.58 & $14.6^{\mathrm{b}}$ & $3.1^{\mathrm{a}}$ & $3.8^{\mathrm{a}}$ & 0.71 \\
\hline \multirow[t]{5}{*}{ Cloxacillin } & Hardness (N) & 20.8 & 19.9 & 0.64 & $27.1^{\mathrm{b}}$ & $17.5^{\mathrm{a}}$ & $16.5^{\mathrm{a}}$ & 0.79 \\
\hline & Adhesiveness (N.s) & -0.93 & -1.15 & 0.077 & $-0.63^{\mathrm{b}}$ & $-1.20^{\mathrm{a}}$ & $-1.30^{\mathrm{a}}$ & 0.094 \\
\hline & Springiness & $0.63^{\mathrm{b}}$ & $0.60^{\mathrm{a}}$ & 0.006 & $0.82^{\mathrm{c}}$ & $0.55^{\mathrm{b}}$ & $0.46^{\mathrm{a}}$ & 0.007 \\
\hline & Cohesiveness & 0.43 & 0.43 & 0.005 & $0.69^{\mathrm{c}}$ & $0.33^{\mathrm{b}}$ & $0.26^{\mathrm{a}}$ & 0.007 \\
\hline & Chewiness (N) & 7.0 & 6.7 & 0.28 & $15.4^{\mathrm{c}}$ & $3.2^{\mathrm{b}}$ & $2.0^{\mathrm{a}}$ & 0.34 \\
\hline \multirow[t]{5}{*}{ Erythromycin } & Hardness (N) & 31.9 & 30.1 & 0.82 & $24.4^{\mathrm{a}}$ & $24.5^{\mathrm{a}}$ & $42.1^{\mathrm{b}}$ & 1.00 \\
\hline & Adhesiveness $(\mathrm{N} \cdot \mathrm{s})$ & -1.95 & -2.02 & 0.081 & $-0.79^{\mathrm{c}}$ & $-2.16^{\mathrm{b}}$ & $-3.00^{\mathrm{a}}$ & 0.099 \\
\hline & Springiness & 0.58 & 0.56 & 0.008 & $0.82^{\mathrm{c}}$ & $0.48^{\mathrm{b}}$ & $0.42^{\mathrm{a}}$ & 0.010 \\
\hline & Cohesiveness & $0.37^{\mathrm{a}}$ & $0.39^{\mathrm{b}}$ & 0.003 & $0.69^{c}$ & $0.23^{\mathrm{b}}$ & $0.21^{\mathrm{a}}$ & 0.004 \\
\hline & Chewiness $(\mathrm{N})$ & 6.8 & 6.8 & 0.39 & $13.8^{\mathrm{b}}$ & $3.0^{\mathrm{a}}$ & $3.7^{\mathrm{a}}$ & 0.48 \\
\hline \multirow[t]{5}{*}{ Ciprofloxacin } & Hardness (N) & 37.4 & 36.2 & 0.74 & $27.9^{\mathrm{a}}$ & $37.3^{\mathrm{b}}$ & $45.2^{\mathrm{c}}$ & 0.91 \\
\hline & Adhesiveness (N.s) & -1.75 & -1.95 & 0.099 & $-1.08^{\mathrm{b}}$ & $-2.28^{\mathrm{a}}$ & $-2.19^{\mathrm{a}}$ & 0.122 \\
\hline & Springiness & 0.59 & 0.57 & 0.009 & $0.82^{\mathrm{c}}$ & $0.51^{\mathrm{b}}$ & $0.42^{\mathrm{a}}$ & 0.011 \\
\hline & Cohesiveness & 0.38 & 0.38 & 0.007 & $0.65^{\mathrm{c}}$ & $0.26^{\mathrm{b}}$ & $0.23^{\mathrm{a}}$ & 0.008 \\
\hline & Chewiness (N) & 8.0 & 8.1 & 0.27 & $14.8^{\mathrm{b}}$ & $4.9^{\mathrm{a}}$ & $4.4^{\mathrm{a}}$ & 0.33 \\
\hline \multirow[t]{5}{*}{ Enrofloxacin } & Hardness (N) & 29.2 & 25.5 & 1.63 & $22.1^{\mathrm{a}}$ & $27.5^{\mathrm{ab}}$ & $32.4^{\mathrm{b}}$ & 1.99 \\
\hline & Adhesiveness $(\mathrm{N} \cdot \mathrm{s})$ & -1.99 & -1.66 & 0.153 & $-0.77^{\mathrm{b}}$ & $-2.35^{\mathrm{a}}$ & $-2.36^{\mathrm{a}}$ & 0.187 \\
\hline & Springiness & 0.60 & 0.60 & 0.010 & $0.84^{\mathrm{c}}$ & $0.52^{\mathrm{b}}$ & $0.43^{\mathrm{a}}$ & 0.012 \\
\hline & Cohesiveness & 0.41 & 0.42 & 0.007 & $0.71^{\mathrm{b}}$ & $0.29^{\mathrm{a}}$ & $0.25^{\mathrm{a}}$ & 0.008 \\
\hline & Chewiness (N) & 7.2 & 6.6 & 0.28 & $13.0^{\mathrm{b}}$ & $4.2^{\mathrm{a}}$ & $3.5^{\mathrm{a}}$ & 0.34 \\
\hline \multirow[t]{5}{*}{ Oxytetracycline } & Hardness $(\mathrm{N})$ & $35.0^{\mathrm{b}}$ & $29.8^{\mathrm{a}}$ & 0.79 & $23.0^{\mathrm{a}}$ & $31.1^{\mathrm{b}}$ & $43.0^{\mathrm{c}}$ & 0.96 \\
\hline & Adhesiveness $(\mathrm{N} \cdot \mathrm{s})$ & -1.55 & -1.48 & 0.061 & $-0.47^{\mathrm{b}}$ & $-2.07^{\mathrm{a}}$ & $-2.01^{\mathrm{a}}$ & 0.075 \\
\hline & Springiness & 0.60 & 0.64 & 0.012 & $0.83^{\mathrm{b}}$ & $0.54^{\mathrm{a}}$ & $0.49^{\mathrm{a}}$ & 0.015 \\
\hline & Cohesiveness & $0.37^{\mathrm{a}}$ & $0.38^{\mathrm{b}}$ & 0.003 & $0.67^{\mathrm{c}}$ & $0.24^{\mathrm{b}}$ & $0.22^{\mathrm{a}}$ & 0.004 \\
\hline & Chewiness (N) & $7.5^{\mathrm{b}}$ & $6.7^{\mathrm{a}}$ & 0.18 & $12.7^{\mathrm{c}}$ & $3.9^{\mathrm{a}}$ & $4.7^{\mathrm{b}}$ & 0.22 \\
\hline
\end{tabular}

\footnotetext{
${ }^{\mathrm{a}-\mathrm{c} S u p e r s c r i p t ~ l e t t e r s ~ w i t h i n ~ a ~ r o w ~ f o r ~ f a c t o r ~ i n d i c a t e ~ s i g n i f i c a n t ~ d i f f e r e n c e s ~}(P<0.05)$.

${ }^{1} \mathrm{AF}=$ antibiotic free; $\mathrm{SM}=$ spiked milk.
} 


\section{Sensorial Analysis of the Cheeses}

The sensory analysis panel did not detect any sensorial differences between the Tronchón SM cheeses containing antibiotics and their respective reference AF cheeses $(P>0.05)$ at $60 \mathrm{~d}$ of ripening. Sensorial differences were detected only in the cheeses from milk containing amoxicillin and erythromycin at MRL concentration, the score values of which are graphically represented as spider web diagrams (Figure 3).

As shown in Figure 3A, the SM cheeses with amoxicillin had lower scores for the odor attribute than the reference cheeses $(P=0.032)$. This could be related to the lower concentration of FFA in the cheeses with the antibiotic (Table 3). The FFA content is closely related to the characteristic aroma of goat milk cheeses and precursors of other high-flavored compounds, such as methyl ketones and lactones (McSweeney and Sousa, 2000; Collins et al., 2003). Regarding mature SM cheeses from goat milk containing erythromycin at a safety level (Figure 3.B), the sensory analysis results indicated significant differences for the attributes odor $(P=0.001)$ and overall preference $(P=0.002)$, which were better valued than the control cheeses by the untrained consumers. Despite these differences, the SM cheeses with these antibiotics were evaluated with high scores (overall preference: 7.3 and 7.1 for amoxicillin and erythromycin, respectively), suggesting a high degree of acceptance by the panelists.

Results herein suggest that the presence of some drug residues in ripened cheeses is undetectable for consumers as they reach high scores for several sensory attributes. Thus, antibiotics such as enrofloxacin, ciprofloxacin, and oxytetracycline, which remain in the cheeses after $60 \mathrm{~d}$ of maturation, did not affect the organoleptic characteristics of the final product in a negative way.

\section{CONCLUSIONS}

The cheese-making process and the quality properties of the ripened goat Tronchón cheeses were only slightly affected by the presence of antibiotics in milk at an equivalent EU MRL concentration. Moreover, the few differences that are related to the FFA concentration, color, and textural properties of the cheeses remained mostly undetected by the sensory analysis panel. However, it is important to emphasize that, depending on the physicochemical properties of the antibiotic, drug residues are transferred from milk to cheese to a greater or lesser extent. In general, antibiotic residues in cheese decrease during ripening. However, large amounts of highly stable substances such as quinolones could re-
A)

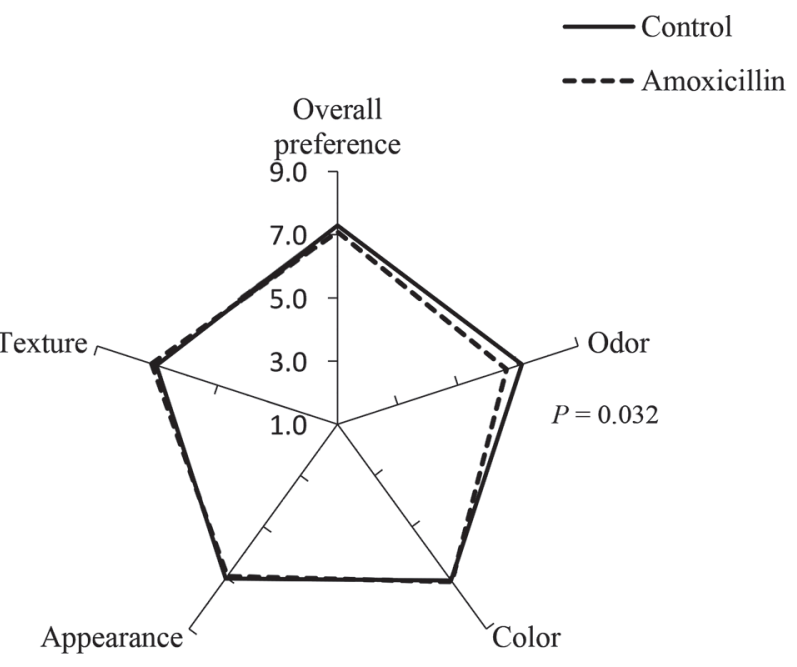

B)

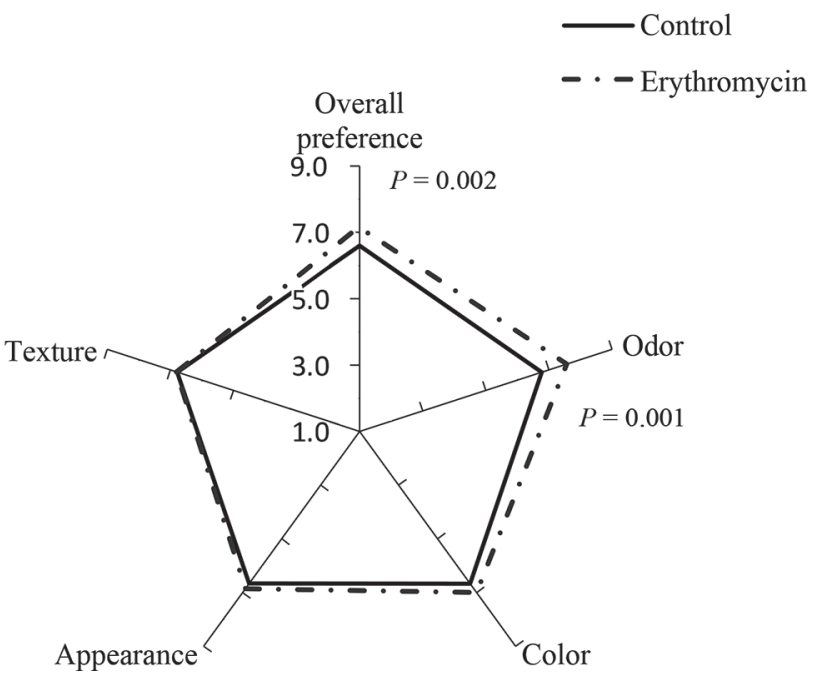

Figure 3. Sensory analysis of Tronchón cheese maturated for 60 d made from goat milk spiked with antibiotic at European Union maximum residue limits concentration. (A) Spider web diagram for amoxicillin; (B) spider web diagram for erythromycin.

main in the final products, posing a potential risk for public health. Therefore, it is necessary to continue to study the retention of antibiotics in cheese made from milk of different species and using specific cheesemaking technologies to establish the corresponding regulations to guarantee the safety of dairy products.

\section{ACKNOWLEDGMENTS}

This work is part of the AGL-2013-45147-R Project funded by Ministerio de Ciencia e Innovación (Madrid, Spain). P. Quintanilla thanks Universitat Politècnica de València (Valencia, Spain) for the grant received for the development of this work (PAID-2014, UPV). 


\section{REFERENCES}

Adetunji, V. O. 2011. Effects of processing on antibiotic residues (streptomycin, penicillin-g and tetracycline) in soft cheese and yoghurt processing lines. Pak. J. Nutr. 10:792-795. https://doi.org/ 10.3923/pjn.2011.792.795.

Arias, M., M. S. García-Falcón, L. García-Río, J. C. Mejuto, R. RialOtero, and J. Simal-Gándara. 2007. Binding constants of oxytetracycline to animal feed divalent cations. J. Food Eng. 78:69-73. https://doi.org/10.1016/j.jfoodeng.2005.09.016.

Beltrán, M. C., R. L. Althaus, A. Molina, M. I. Berruga, and M. P. Molina. 2015. Analytical strategy for the detection of antibiotic residues in sheep and goat's milk. Span. J. Agric. Res. 13. https:/ /doi.org/10.5424/sjar/2015131-6522.

Berruga, M. I., A. Molina, R. L. Althaus, and M. P. Molina. 2016. Control and prevention of antibiotic residues and contaminants in sheep and goat's milk. Small Rumin. Res. 142:38-43. https://doi .org/10.1016/j.smallrumres.2016.02.023.

Bodart, M., R. de Peñaranda, A. Deneyer, and G. Flamant. 2008. Photometry and colorimetry characterisation of materials in daylighting evaluation tools. Build. Environ. 43:2046-2058. https:// doi.org/10.1016/j.buildenv.2007.12.006.

Buffa, M., B. Guamis, M. Pavia, and A. J. Trujillo. 2001. Lipolysis in cheese made from raw, pasteurized or high-pressure-treated goats milk. Int. Dairy J. 11:175-179. https://doi.org/10.1016/S0958 -6946(01)00044-9.

Cabizza, R., N. Rubattu, S. Salis, M. Pes, R. Comunian, A. Paba, M. Addis, M. C. Testa, and P. P. Urgeghe. 2017. Transfer of oxytetracycline from ovine spiked milk to whey and cheese. Int. Dairy J. 70:12-17. https://doi.org/10.1016/j.idairyj.2016.12.002.

Cabizza, R., N. Rubattu, S. Salis, M. Pes, R. Comunian, A. Paba, E. Daga, M. Addis, M. C. Testa, and P. P. Urgeghe. 2018. Impact of a thermisation treatment on oxytetracycline spiked ovine milk: Fate of the molecule and technological implications. Lebensm. Wiss. Technol. 96:236-243. https://doi.org/10.1016/j.lwt.2018.05.026.

Carreira, A., K. Dillinger, F. Eliskases-Lechner, V. Loureiro, W. Ginzinger, and H. Rohm. 2002. Influence of selected factors on browning of Camembert cheese. J. Dairy Res. 69:281-292. https://doi .org/10.1017/S0022029902005393.

Carvalho, F., A. R. Prazeres, and J. Rivas. 2013. Cheese whey wastewater: Characterization and treatment. Sci. Total Environ. 445446:385-396. https://doi.org/10.1016/j.scitotenv.2012.12.038.

Chen, S. X., J. Z. Wang, J. S. Van Kessel, F. Z. Ren, and S. S. Zeng. 2010. Effect of somatic cell count in goat milk on yield, sensory quality, and fatty acid profile of semisoft cheese. J. Dairy Sci. 93:1345-1354. https://doi.org/10.3168/jds.2009-2366.

Chilliard, Y., A. Ferlay, J. Rouel, and G. Lamberet. 2003. A review of nutritional and physiological factors affecting goat milk lipid synthesis and lipolysis. J. Dairy Sci. 86:1751-1770. https://doi.org/10 .3168/jds.S0022-0302(03)73761-8.

Choi, K. H., H. Lee, S. Lee, S. Kim, and Y. Yoon. 2016. Cheese microbial risk assessments - A review. Asian-australas. J. Anim. Sci. 29:307-314. https://doi.org/10.5713/ajas.15.0332.

Collins, Y. F., P. L. H. McSweeney, and M. G. Wilkinson. 2003. Lipolysis and free fatty acid catabolism in cheese: A review of current knowledge. Int. Dairy J. 13:841-866. https://doi.org/10.1016/ S0958-6946(03)00109-2.

Delgado, F. J., J. González-Crespo, R. Cava, and R. Ramírez. 2011. Proteolysis, texture and colour of a raw goat milk cheese throughout the maturation. Eur. Food Res. Technol. 233:483-488. https:/ /doi.org/10.1007/s00217-011-1536-3.

Dethlefsen, L., S. Huse, M. L. Sogin, and D. A. Relman. 2008. The pervasive effects of an antibiotic on the human gut microbiota, as revealed by deep 16S rRNA sequencing. PLoS Biol. 6:e280. https: //doi.org/10.1371/journal.pbio.0060280.

European Union. 2002. Commission Decision 2002/657/EC of $12 \mathrm{Au}-$ gust 2002 implementing Council Directive 96/23/EC concerning the performance of analytical methods and the interpretation of results. Off. J. L 221:8-36.

European Union. 2009. Regulation (EC) № 470/2009 of 6 May 2009 laying down Community procedures for the establishment of resi- due limits of pharmacologically active substances in foodstuffs of animal origin, repealing Council Regulation (EEC) № 2377/90 and amending Directive 2001/82/EC of the European Parliament and of the Council and Regulation (EC) № 726/2004 of the European Parliament and of the Council. Off. J. L 152:11-22.

European Union. 2010. Regulation (EU) no. 37/2010 of 22 December 2009 on pharmacologically active substances and their classification regarding maximum residue limits in foodstuffs of animal origin. Off. J. L 15:1-72.

Everett, D. W., and M. A. E. Auty. 2008. Cheese structure and current methods of analysis. Int. Dairy J. 18:759-773. https://doi.org/10 .1016/j.idairyj.2008.03.012.

FAO/OIE/WHO (Food and Agriculture Organization of the United Nations/World Organization for Animal Health/World Health Organization). 2018. Monitoring global progress on addressing antimicrobial resistance: Analysis report of the second round of results of AMR country self-assessment survey 2018. Accessed Oct. 24, 2018. http://apps.who.int/iris/bitstream/handle/10665/273128/ 9789241514422-eng.pdf

FAOSTAT (Food and Agriculture Organization of the United Nations). 2018. Food and agriculture data. Accessed Jul. 26, 2018. http://www.fao.org/faostat/en/\#data/QL/visualize.

FAO/WHO (Food and Agriculture Organization of the United Nations/World Health Organization). 2004. Evaluation of certain food additives and contaminants: Sixty-second report of the Joint FAO/WHO Expert Committee on Food Additives. FAO/WHO, Geneva, Switzerland.

FDA (Food and Drug Administration). 2018. MI-18-09: Tolerance and/or target testing levels of animal drug residues in milk. Accessed Jul. 24, 2018. https://www.fda.gov/downloads/Food/ GuidanceRegulation/GuidanceDocumentsRegulatoryInformation/ Milk/UCM596680.pdf.

Fenelon, M. A., P. O'Connor, and T. P. Guinee. 2000. The effect of fat content on the microbiology and proteolysis in Cheddar cheese during ripening. J. Dairy Sci. 83:2173-2183. https://doi.org/10 .3168/jds.S0022-0302(00)75100-9.

Ferrandini, E., M. B. López, M. Castillo, and J. Laencina. 2011. Influence of an artisanal lamb rennet paste on proteolysis and textural properties of Murcia al Vino cheese. Food Chem. 124:583-588. https://doi.org/10.1016/j.foodchem.2010.06.079.

Folkertsma, B., and P. F. Fox. 1992. Use of the Cd-ninhydrin reagent to assess proteolysis in cheese during ripening. J. Dairy Res. 59:217-224. https://doi.org/10.1017/S0022029900030466.

Freitas, C., and F. X. Malcata. 2000. Microbiology and biochemistry of cheeses with Appélation d'Origine Protegée and manufactured in the Iberian Peninsula from ovine and caprine milks. J. Dairy Sci 83:584-602. https://doi.org/10.3168/jds.S0022-0302(00)74918-6.

Fresno, M., and S. Álvarez. 2012. Chemical, textural and sensorial changes during the ripening of Majorero goat cheese. Int. J. Dairy Technol. 65:393-400. https://doi.org/10.1111/j.1471-0307.2012 $.00842 . x$

Gajda, A., E. Nowacka-Kozak, M. Gbylik-Sikorska, and A. Posyniak. 2018. Tetracycline antibiotics transfer from contaminated milk to dairy products and the effect of the skimming step and pasteurisation process on residue concentrations. Food Addit. Contam. A Chem. Anal. Control Expo. Risk Assess. 35:66-76. https://doi .org/10.1080/19440049.2017.1397773.

Giguère, S. 2013. Antimicrobial drug action and interaction. Pages 1-10 in Antimicrobial Therapy in Veterinary Medicine. 5th ed. S. Giguère, J. F. Prescott, and P. M. Dowling, ed. Wiley-Blackwell, Ames, IA.

Giraldo, J., R. L. Althaus, M. C. Beltrán, and M. P. Molina. 2017. Antimicrobial activity in cheese whey as an indicator of antibiotic drug transfer from goat milk. Int. Dairy J. 69:40-44. https://doi .org/10.1016/j.idairyj.2017.02.003.

Grunwald, L., and M. Petz. 2003. Food processing effects on residues: Penicillins in milk and yoghurt. Anal. Chim. Acta 483:73-79. https://doi.org/10.1016/S0003-2670(02)01405-8.

Haenlein, G. F. W. 2004. Goat milk in human nutrition. Small Rumin. Res. 51:155-163. https://doi.org/10.1016/j.smallrumres.2003 .08 .010 . 
ISO (International Organization for Standardization). 2003. Sensory analysis - Guidelines for the use of quantitative response scales. Standard number 4121:2003. ISO, Geneva, Switzerland.

ISO/IDF (International Organization for Standardization/International Dairy Federation). 2003. Milk and milk products. Guidelines for a standardized description of microbial inhibitor tests. Standard number 183:2003. ISO, Geneva, Switzerland.

Jeong, S. H., Y. K. Song, and J. H. Cho. 2009. Risk assessment of ciprofloxacin, flavomycin, olaquindox and colistin sulfate based on microbiological impact on human gut biota. Regul. Toxicol. Pharmacol. 53:209-216. https://doi.org/10.1016/j.yrtph.2009.01.004.

Juan, B., A. Zamora, J. M. Quevedo, and A. J. Trujillo. 2016. Proteolysis of cheese made from goat milk treated by ultra high pressure homogenisation. Lebensm. Wiss. Technol. 69:17-23. https:// doi.org/10.1016/j.lwt.2015.12.013.

Katla, A. K., H. Kruse, G. Johnsen, and H. Herikstad. 2001. Antimicrobial susceptibility of starter culture bacteria used in Norwegian dairy products. Int. J. Food Microbiol. 67:147-152. https://doi .org/10.1016/S0168-1605(00)00522-5.

Lees, P. and P. L. Toutain. 2011. Pharmacokinetics, distribution, bioavailability, and relationship to antibiotic residues. Pages 61-109 in Chemical Analysis of Antibiotic Residues in Food. J. Wang, J. D. MacNeil, and J. F. Kay, ed. Wiley, Hoboken, NJ.

Lucas, A., E. Rock, J. F. Chamba, I. Verdier-Metz, P. Brachet, and J. B. Coulon. 2006. Respective effects of milk composition and the cheese-making process on cheese compositional variability in components of nutritional interest. Lait 86:21-41. https://doi.org/ 10.1051/lait:2005042.

McSweeney, P. L. H., and M. J. Sousa. 2000. Biochemical pathways for the production of flavour compounds in cheeses during ripening: A review. Lait 80:293-324. https://doi.org/10.1051/lait:2000127.

Merin, U., G. Fleminger, J. Komanovsky, N. Silanikove, S. Bernstein, and G. Leitner. 2008. Subclinical udder infection with Streptococcus dysgalactiae impairs milk coagulation properties: The emerging role of proteose peptones. Dairy Sci. Technol. 88:407-419. https://doi.org/10.1051/dst:2008022.

Nuñez, M., C. García-Aser, M. A. Rodríguez-Martin, M. Medina, and P. Gaya. 1986. The effect of ripening and cooking temperatures on proteolysis and lipolysis in Manchego cheese. Food Chem. 21:115123. https://doi.org/10.1016/0308-8146(86)90156-1.

Oliver, S. P., S. E. Murinda, and B. M. Jayarao. 2011. Impact of antibiotic use in adult dairy cows on antimicrobial resistance of veterinary and human pathogens: A comprehensive review. Foodborne Pathog. Dis. 8:337-355. https://doi.org/10.1089/fpd.2010.0730.
Park, Y. 2017. Goat milk-Chemistry and nutrition. Pages $42-83$ in Handbook of Milk of Non-Bovine Mammals. 2nd ed. Y. W. Park, G. F. W. Haenlein, and W. L. Wendorff, ed. Wiley-Blackwell, Oxford, UK.

Reeves, P. T. 2011. Antibiotics: Groups and properties. Pages 1-60 in Chemical Analysis of Antibiotic Residues in Food. J. Wang, J. D. MacNeil, and J. F. Kay, ed. Wiley, Hoboken, NJ.

Revilla, I., J. M. Rodríguez-Nogales, and A. M. Vivar-Quintana. 2007. Proteolysis and texture of hard ewes' milk cheese during ripening as affected by somatic cell counts. J. Dairy Res. 74:127-136. https: //doi.org/10.1017/S0022029906002342.

Roca, M., L. Villegas, M. L. Kortabitarte, R. L. Althaus, and M. P. Molina. 2011. Effect of heat treatments on stability of $\beta$-lactams in milk. J. Dairy Sci. 94:1155-1164. https://doi.org/10.3168/jds .2010-3599.

Roca, M. I. 2008. Termoestabilidad de sustancias antimicrobianas en la leche. PhD Thesis. Universitat Politècnica de València, Valencia (Spain).

Salvador, A., M. Igual, C. Contreras, N. Martínez-Navarrete, and M. M. Camacho. 2014. Effect of the inclusion of citrus pulp in the diet of goats on cheeses characteristics. Small Rumin. Res. 121:361367. https://doi.org/10.1016/j.smallrumres.2014.06.012.

Shappell, N. W., W. L. Shelver, S. J. Lupton, W. Fanaselle, J. M. Van Doren, and H. Hakk. 2017. Distribution of animal drugs among curd, whey, and milk protein fractions in spiked skim milk and whey. J. Agric. Food Chem. 65:938-949. https://doi.org/10.1021/ acs.jafc.6b04258.

Stolker, A. A. M., and U. A. T. Brinkman. 2005. Analytical strategies for residue analysis of veterinary drugs and growth-promoting agents in food-producing animals - A review. J. Chromatogr. A 1067:15-53. https://doi.org/10.1016/j.chroma.2005.02.037.

Tejada, L., R. Gómez, and J. Fernández-Salguero. 2007. Sensory characteristics of ewe milk cheese made with three types of coagulant: Calf rennet, powdered vegetable coagulant and crude aqueous extract from Cynara cardunculus. J. Food Qual. 30:91-103. https:// doi.org/10.1111/j.1745-4557.2007.00108.x.

Thierry, A., Y. F. Collins, M. C. Abeijón Mukdsi, M. G. Wilkinson, and H. E. Spinnler. 2017. Lipolysis and metabolism of fatty acids in cheese. Pages 423-444 in Cheese: Chemistry, Physics and Microbiology. 4th ed. P. L. H. McSweeney, P. F. Fox, P. Cotter, and D. Everett, ed. Academic Press, London, UK. 